\title{
Women's Movement For Peace: Global Overview
}

\author{
Nafisa Bano \\ Women's Studies \\ University of Karachi
}

\begin{abstract}
Over the years, a realization has slowly but surely grown that war is, after all, not a good thing to happen and it is deadly and devastating for the universe. Especially, the realization about the sufferings of women and children caught in wars, armed conflicts and violence has increased. The women doubtless suffer most because of their vulnerable position.

A series of women movements and organizations focusing on women issues are actively campaigning for peace for women today. Women, mostly belonging to North American and European countries, are active in the process of developing peace through writings, lectures, conferences, seminars, workshops and networking in different countries and establishing and empowering organizations to form a broad base for further action. In this context, several women constituencies are playing a very important role in the movement against nuclear weapons. Likewise, the women Nobel Peace Laureates' role for global peace is very inspiring.
\end{abstract}

\section{تلخيص المقال}

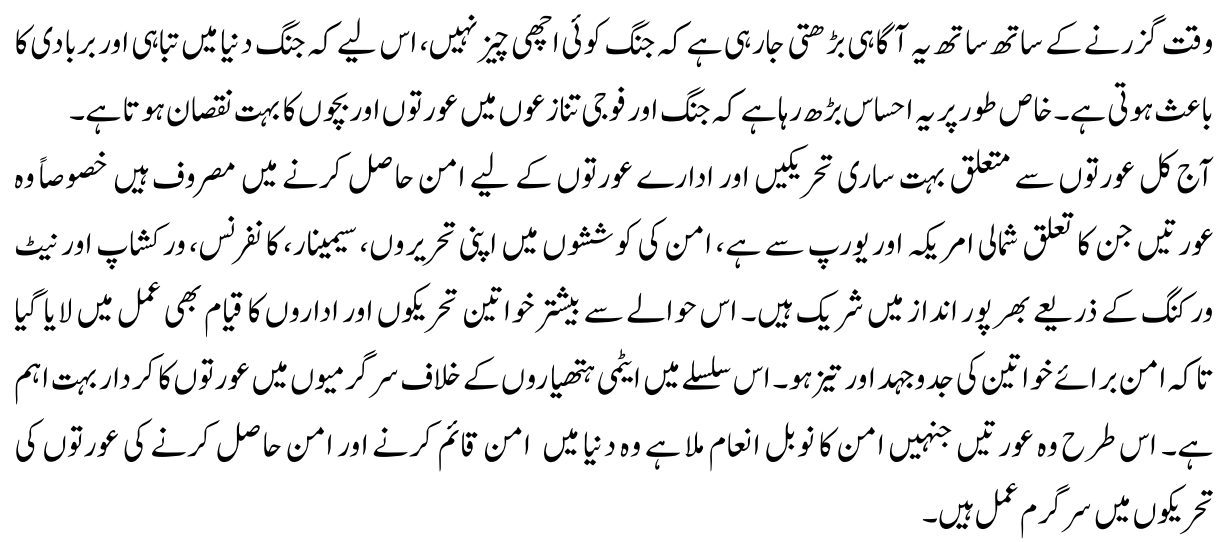

\section{Introduction}

Recorded history is largely about conflicts and wars between tribes, communities, nations, kingdoms, empires and states. It is all about the conquerors and the conquered and about territories gained and territories lost. It is only in the recent times that history of the peoples of the world is being compiled, prepared and published. This is a kind of history which focuses on human struggle for political and social change. Also described as Peace history ${ }^{1}$, it is essentially about the heroic movements for human rights, freedom, 
development and peace. What is surprising about this history of peace is the invisibility of women in it. Women do not constitute an important part of such studies and the movements waged by women in different eras and in different societies are still only marginally referred to. (Carrol. 1998, pp 19-33)

Related to it is another dimension calling for our attention. It is generally believed that women activism began after World War II. True enough that the long, devastating War (1939 - 1945) brought into sharp focus the sufferings of women and children and prompted women's movement for peace and equal rights in Europe and North America in particular. But women's movement for peace and equal rights has a long history of its own.

\section{Women's Movement for Peace:19th Century and Before}

More than two hundred years ago, France was rocked by the revolutionary tempest. People from all over France came out into the streets and demanded their rights. The French women actively participated in this giant struggle. They formed women republican clubs all over France and through its platform, pleaded that the rights of liberty, equality and fraternity should apply to all, regardless of sex. In England, Mary Wallstone Craft wrote the first major feminist work, which demanded equality for women. It was titled 'A Vindication of the Rights of Women'. A little over half a century later, in 1848, more than 100 women held the 1st Women's Right Convention at Sencea Falls in New York. It was led by the abolitionist Lucretia Mott and Elizabeth Cancy Stanston. They demanded equal rights for women, including the right to vote. Susan B. Anthony, Sojourner Truth, Alice Paul and many others also struggled for voting rights. Married Women's Property Act was passed in 1870. Later, provisions were made for divorce, maintenance payments and child support. Labour legislations were introduced which improved working hours and wages for women. Indeed, the history of women's movement for equal rights is a record of remarkable role played by women in different continents, regions and countries.

Further more, it was between 1820 and 1830 that the first All Women National Peace Societies were founded in England and in America (Random, 1993 pp 108). In 1840, the French - Peruvian activities were in full flow. Flora Tristan Moscosa traveled around the world promoting her plan for a world wide worker's international organization and a socialist movement was born in 1840s. In 1882, when Louise Michael broke into the bakeries of Lyon to distribute bread among the poor, she was trying to give shape to the desperate but unorganized movement of house wives in the $1700 \mathrm{~s}$, who used to beg for bread. She also has the credit of founding the new socialist - anarchist vision of a post imperial society. During 1880 - 1900, Clara Zeltkin and Rosa Luxembourg articulated the vision of an International Socialist Community based on nonviolence and repudiation of nationalism. 
Women activist groups sprang up all over Europe throughout the second half of the 19th century. Here one may refer to the efforts of Priscilla Peckover, an English Quaker, who built up an International Network of Women. Members of this group who were based in the US, France, Russia, Rome, Hanover, Warsaw, Portugal, Polynesia and Constantinople.

Bertha von Suttner $(1843$ - 1914) is another notable woman whose contribution in enhancing peace awareness in Austria and beyond is substantial. Writing with another name, she published a novel Die - Waffen Bierder (Lay Down Your Arms) in 1894. It was one of Bertha's novels on the absurdity of armament. This novel produced storms in the corridors of power in Europe. Later she persuaded Alfred Nobel to found a peace prize. Thus the Nobel Peace Prize was established.(Utne, 1985, pp 37-45)

Another notable woman who may be mentioned here is the American peace campaigner Jane Addams. She helped convene a group of women at the Hague during World War I. This group campaigned against wars and produced studies to create alternative institutions which would prove to be instrumental in promoting the diplomacy of peace.

One may add here that the women have been fighting for their rights and for peace and justice for a fairly long period of time. History records their struggle even during the ancient period. In ancient Greece, for example, Lysistrata, one of the great literary works, expressed in action through dramas that women of the Iroguois nation threatened to boycott love - making and child bearing until men conceded some of their powers in decisions about war and peace.(Utne, 1985 pp. 37) Further glorious examples can also be found in numerous struggles for the rights waged by the women. For instance, women under the leadership of Anne Hutchinson and Mary Dyer fought nonviolently for religious freedom in the Massachusetts Bay Colony. Many other women, including Lucretia Mott, Sarah and Angelina Grimke also struggled hard to end slavery.

\section{Women's Movement for Peace: $2^{\text {th }}$ Century}

However, women's struggle in the past was largely disorganized and scattered. It became more focused, when the women struggled to prevent war and establish political and social peace. Many women struggled for real and stable peace. For example, Jannette Rankin's efforts to avoid World War I contributed to the foundation of the Women's International League of Peace and Freedom (WILPF). The traditional women's peace movement focused primarily on war and international conflict. Yet beneath the efforts to prevent war and promote peace, women were always pre - occupied by the underlying causes and problems of economic and social justice as well as issues of political freedom for individuals as well as for the society. Women's peace work were mostly structured by non - governmental organizations. Such organizations were mostly formed during the first half of the 20th century in industrialized countries in Western Europe and the US. 
Women joined such NGOs in large number and actively campaigned against war, violence and injustice.

An event of extraordinary significance took place in 1915 when women from 13 countries came together in the Hague to protest against war and to think of ways to stop it. These women belonged to the countries which were at war with one another. Some also belonged to the neutral states. This meeting was the starting point of the WILPF. These women worked out a manifesto that included a proposal for the establishment of a permanent institution of arbitration. The meeting was held in 1915, before the creation of the League of Nations. The meeting appointed delegations of women, who visited all the states that were involved in the First World War as well as those who were neutral. They presented their manifestos to the governments and the leaders of these states. The representatives of 35 governments received these delegations.(Utne, 1985 pp. 45)

After the First World War, WILPF sent a proposal to the Peace Conference in Paris in 1919, suggesting measures to avoid a fresh world war. One of the major aims of WILPF was to bring together women of different political and philosophical mindsets, who were determined to study, identify the obstacles to peace, help to abolish/reduce the political, social, economic and psychological causes of war and work for constructive peace. The WILPF has consultative status with the UN Social and Economic Council and with its specialized agencies UNESCO, ILO, etc. The WILPF continues its struggle against war, violence and injustice and frequently organizes international conferences. One of the largest meetings sponsored by the WILPF sponsored was held in Amsterdam in 1981. More than 500 women from 25 countries attended this meeting and passed important resolutions calling for the installation of a regime of international peace. WILPF continues to play an active role in promoting awareness regarding the tragic consequences of wars and conflicts especially for women and children and promoting the cause of peace.

\section{The Irish Peace Women}

But WILPF is not the only organization of women that has campaigned against war. As a matter of fact, thousands of women organizations have been struggling all over the world against wars, violence and internal conflicts in many countries and building up strong resistance groups. We may refer here to the formation of the group known as Irish Peace Women. It came into existence after an incident in Ireland in which three small children were in their pram and their mother was mutilated. The aunt of the children, Mairead Corrigan, expressed her protest on T.V. and reached the hearts of most mothers. At the same time Betty Williams and other women also started a campaign against the tragedy. She gave her telephone number in the newspapers and advised women to contact her. Within 48 hours, Betty Williams and others had obtained 6000 signatures to a petition demanding an end to the acts of war. Betty Williams and Mairead Corrigan planned a 
peace march the day after the funeral of the three children. More than 10,000 people attended this march. Most of the marchers were mothers who marched with their children and the elderly people. It was held in total silence in August 1976. It marked the starting point of the Peace People Movement in Northern Ireland. Three months after the first March, more than 150,000 people had participated in different marches to demonstrate their desire for lasting peace in Northern Ireland.(Unte, 1985, pp 46-47) Let it be emphasized that women are active not only in Northern Ireland but in numerous other countries and regions to establish the regime of peace.

\section{Women against Nuclear Weapons}

Women, one may point out here, have been in the forefront of the global campaign against nuclear weapons as well. The Nordic women, for example, very bravely campaigned against militarism and nuclearism. When it was learnt in December 1979 that NATO would install intermediate range nuclear missiles in West and Central Europe, women established an organization called Women for Peace and resolved that the NATO action had to be restricted through peaceful means. This Nordic organization was formed by the Danish and Finnish women who met at a kitchen table in Copenhagen around the same time. The forum prepared a common text for action. It was adopted in Oslo on 22nd January 1980. It states:

"We have more and more come to realize that women all over the world nourish the same thoughts and the same fears. Do my children have any future? Together with women all over the world we want to turn our powerlessness into strength. We cannot any longer silently accept the power game between the superpowers. All acts of aggression must be stopped and the disarmament negotiations must be continued and must lead to action and real disarmament."

In addition, the organization demanded: a) disarmament to secure a lasting peace; $b$ ) food instead of arms; and 3) no to war!(Utne, 1985, pp-88)

This manifesto was translated into different languages. It was also widely distributed. It called upon the women of all Nordic countries-women of Denmark, Finland, Greenland, Iceland, Norway and Sweden- to sign an attached petition. By June 1980, more than half a million signatures had been collected. This, along with the manifesto, was submitted to the UN Secretary General Kurt Waldheim. The timing for this initiative was perfect. The Secretary General was approached at a time when the UN Conference on Women was about to take place in Copenhagen. In the conference, women delegates from all over the world urged the leaders of Women for Peace to continue their work. Subsequently Women for Peace prepared pamphlets and studies challenging NATO's military doctrine and also alerted Europe against the consequences of nuclearization. (Unte 1985 pp 48-50) 
Besides the Nordic women, women in several other countries in Europe and North America also actively participated in the campaign against nuclear and conventional weapons. In 1981, for example, 40 Welsh women, among whom many had young children in strollers, marched in protest against the planned installation of 93 cruise missiles during the 1980s. They arrived on 5th September 1981 at Greenham Common (located near Newbury in Berkshire) and submitted a petition to the base commandant and stated their reason for the march. It was an important issue taken up by women, but the media totally ignored their effort. Then the women decided to camp outside the base and form a base camp. At the beginning, they slept under the open sky in sleeping bags. Later the tents were erected there. In December 1983, the first cruise missiles were sited at the Greenham Common, where the Welsh women had camped for 2 years. Many times women were forcibly moved away, but they returned again and continued their struggle.

Defending their peace action, the women of the camp said: “... as women we have been actively encouraged to stay at home and look to men as protectors. Now it is the time to reject this role."

These women had left their families and friends and they continued to live in tents where there was no electricity and heating facility during the winter. But they were not bothered by these hardships. They had strong faith in their mission. They believed that they were acting very responsibly by preventing the cruise missiles from entering Britain and they were trying to save life on the planet.(Utne 1985 pp 50)

\section{Women peace activism outside Europe and North America}

Peace activism, one may point out, is not the privilege of the women of developed European and North American societies only. The women of the developing societies are also in the forefront of the struggle for peace, justice, dignity, freedom and welfare. Here one may refer to several groups of courageous women who are working for peace and human rights in the South. One such group is known as Argentinean Mothers of Plaza de Mayo. During the military rule in Argentine from 1976 to 1983, thousands of Argentineans had disappeared. They were either murdered or imprisoned. The women of the country formed an organization and registered their protest by staging a silent demonstration in front of the palace of the President at the Plaza de Mayo every Thursday. Wearing white handkerchiefs on their heads, they protested against the torturing, killing and lack of respect for life in their country. They also protested against war. Many mothers were imprisoned and some also 'disappeared.' These mothers were prevented from demonstrating at their usual place from January 1979 onward, but they continued to meet in the surrounding churches every Thursday. They claimed that their courage, strength and perseverance came from a universal feeling of motherhood and caring.(Utne 1985, pp 50) 
A yet another women's group actively campaigning against wars and weapons ---especially since 1980s--- is known as the Women for Survival. It was organized by women all over Australia. Being concerned for the dangers of an arms race, these women organized their camp outside Pine Gap and through satellite communication, they got connected with various peace movements, including those at Greenham Common, West Germany, Eastern Europe and Russia. They said that the kind of transformation that is needed to reverse the arms race can come from women's movements which were growing and gaining strengthening throughout the world.

\section{UN and Women's Movement for Peace}

Peace activities by women's groups in the developed and developing societies brought into sharp focus the grave consequences of war, violence and injustices for the people of the world in general and for women and children in particular. A number of women working within the UN system or belonging to international civil society helped, assisted and encouraged the United Nations to play an important role in projecting the importance of peace for women, encouraging the governments and civil societies to initiate concrete steps to empower women and to highlight the role of women in promoting peace in different regions and in different societies.

As a matter of fact, ever since its creation the United Nations has been concerned with women issues and helped and assisted the global movement for peace and for women's rights. To be more specific, the Commission on the Status on Women(CSW) was one of the first bodies established by the UN Economic and Social Council. It was established way back in 1946 and given the task to promote awareness regarding women's problems, monitor the situation of women, promote their rights all over the world and prepare recommendations and reports for the UN on any issue affecting women. Ever since its creation, the CSW dealt with numerous issues relating to women's participation in political life and in the decision-making process, women's role in peace-building and in their contribution to development .In addition, it also put forward policy recommendations regarding women's rights in employment and in education, and their role in the economy and environment. It is well known in the concerned circles as a global advocate for equality between men and women. And since the adoption of the Universal Declaration of Human Rights (UDHR) in 1948, the UN and its numerous bodies have been actively promoting equal rights for women and for a peaceful world for the women and children in particular. Again, the UN conferences on Children in New York in 1990, Environment and Development at Rio de Janerio in 1992 , Human Rights in Vienna in 1993 , Population and Development in Cairo in 1994 , Social Development in Copenhagen in 1995 and Habitat II on Human Settlements in Istanbul in 1996 and World Food Conference in Rome in 1996 also contributed to the process for the enhancement of global awareness on women issues and women's status in the societies. 
The campaign for women's advancement by the UN gathered momentum with the proclamation of 1975 as International Year for Women and holding of the first major conference on the status of women in Mexico City. This conference expanded working relationship between $\mathrm{UN}$ and NGOs and also led to the elucidation of a three part theme equality, development and peace- which became the basis for the organization's work for women in the years to follow. By 2nd July 1975, the Commission adopted a world.

Plan of Action: Declaration of Mexico on the Equality of Women and their Contribution to Development and Peace.

There were 30 separate principles in the Declaration, including the elimination of all obstacles in granting women opportunities to fully integrate into national development and peace. In the words of the Declaration, "Women must participate equally with men in the decision-making process which helps to promote peace at all levels." In the same conference, the UN was urged to proclaim the period from 1976 to 1985 as the UN decade for women and development.(United Nations. 1995)

The Decade for Women is known for its historic events, including the holding of the Copenhagen and Nairobi conferences and the adoption of the 1979 Convention on the Elimination of All Forms of Discrimination Against Women(CEDAW). During this period, it was realized that development was not possible without the full participation of women. It was also acknowledged that under-valuation of women was a major cause for underdevelopment. Accordingly, the UN conference for women held at Copenhagen in 1980 discussed in great detail the issues relating to conflicts, underdevelopment and women and declared that it would seriously work for women rights and women's happiness. In this context, it made it clear that it would not sit idle after passing resolution ,but review the progress of implementing the goals of the Mexico City Conference and update the 1975 World Plan of Action.

During the Nairobi conference held in 1985, strategies were suggested for the grant of equal status to women at national level. It identified three basic categories where implementation could be recommended. These were:a) constitutional and legal rights; b) equality in social participation; and c) equality in political participation and decisionmaking. Furthermore, concerted efforts were made to forge solid linkages between the UN and the civil society. Ten years later, a major conference on women was organized by the UN at Beijing, People's Republic of China. Over 40, 000 women from around the world and government delegates from 189 countries participated in this conference. It demanded that the governments should improve women's status and respect women's rights and the governments participating in the conference pledged to fight violence against women in all its forms. It also intensified efforts to bring the UN and the civil society closer .Accordingly, the NGO Working Group on Women ,Peace and Security (NGOWG) was formed in May 2000 which campaigned for a UN Security Council resolution on women, peace and security. At its 4213th meeting held in October 2000, 
the Security Council adopted its 1325 th resolution calling upon the member states to take steps to ensure women's security in conflict situations and afterwards.

The NGOWG did'nt sit idle after getting the resolution passed by the Security Council .It has intensified its efforts for its implementation by the governments and it has become a strong coalition of major civil society campaigners including Amnesty International, Boston Consortium on Gender and Security, Femmes Africa Solidarite, Global Action to Prevent War, Hague Appeal for Peace, Human Rights Watch, International Alert, International Women's Tribune Centre, Women's Action for New Directions, The Women's Commission for Refugee Women and Children, Women's Division of General Board of Global Minorities, Women's Environment and Development Organization and Women's International League for Peace and Freedom.

Even a cursory glance at the proceedings of above and several other international events may suggest that the UN has been trying to elevate the status of women and encourage them to be at the very centre of the movement for global, social and political change. And these efforts are linked to the attainment of the goals of UN Charter, which include:

a) maintenance of international peace and security ; b) protection of human rights ;c) creation of an environment of respect for international law ; and d) promotion of economic and social well- being for all human beings.

\section{Women Nobel Peace Laureates ${ }^{2}$}

While the UN may be appreciated for highlighting the importance of women in peacebuilding at global, regional and local level, one should also acknowledge the remarkable services to peace rendered by women peace scholars, activists and specially those who were awarded the Nobel Peace Prize. Indeed, Women Nobel Peace Laureates are a source of great inspiration for the entire global humanity and especially for women peace activists and scholars everywhere, including Pakistan. A brief insight into their lives and their struggles may suggest as to how remarkable these women for peace were.

Bertha Von Suttner: Alfred Nobel was the founder of the Nobel Prizes, which are awarded in the fields of literature, economics, peace, medicine and sciences every year. Nobel had amassed a lot of wealth with his invention of the dynamite. He wanted to invest his wealth into noble causes. He used to read a lot and was very much impressed by the writings of a certain Bertha von Suttner, who had earlier worked for several weeks as his secretary. Both were in contact with each other and Nobel greatly appreciated her works that were related to peace.

Bertha wrote many books, but these were published under various pseudonyms. The reason she gave was the prevalence of wide discrimination against women and also because of the general belief that creativity and women had as much chance of being 
together as the two poles of a magnet coming together. Her most widely - read books are Das Maschinenzeitalter (The Age of Machines) and Die Waffer Nierder (Lay Down Your Arms).

Bertha urged Nobel to donate a part of the money he earned through his invention of the dynamite to the creation of a Peace Prize in order to promote the cause of peace. In January 1893, Nobel wrote to Bertha and told her that he had decided to accept her suggestion and was ready to donate a part of his wealth for the establishment of a peace prize which would be awarded to a person or persons who had worked in the best way to further the brotherhood of man for disarmament and for organizing peace conferences.

Berth-a woman, therefore, proved to be the main driving force behind the establishment of the most coveted peace prize of the world. She also earned the distinction of becoming the first ever woman Nobel Peace Laureate when she received the Nobel Peace Prize in 1905. In many countries, people were of the view that she should have been the first ever recipient of the Prize, but alas, it was not to be.

Jane Adams: 26 years after Bertha von Suttner received the Nobel Peace Prize, another woman, Jane Adams, received the Nobel Peace Prize in 1931. She received this prize along with co-recipient Nicholas Murray Butler. She was the first female American to get this coveted prize. Adams had vigorously campaigned against First World War. She was also a founding member of Women's International League for Peace and Freedom (WILPF), which was a great champion of peace during the early and mid 20th century.

Emily Greene Balch: Emily Greene Balch is another woman famous for her peace activism. She received the Nobel Peace Prize along with the founder of YMCA, John Mott, in 1946. Balch was a colleague of Jane Adams and had campaigned with her against the First World War. She also worked hard in 1926 for the withdrawal of US troops from Haiti, which was under occupation for nearly 11 years. She was forced to resign from her job of a teacher of social economics at Wellesley College, where she had been working for 20 years. She was victimized by her school for her pacifist activities during the First World War. She was one of the staff at the WILPF's headquarters in Geneva and was also its representative at the League of Nations.

Betty Williams and Mairead Corrigan: Both of these great women were founding members of an organization called Irish Peace Women. They were jointly awarded the Nobel Peace Prize in 1976. They had worked vigorously for the cause of peace and organized several peace marches in the Northern Ireland against the killing of three children, who were in their prams and injuring their mother. These women organized a peace march a few days after the funeral of the children. Several women, including mothers of small children, and elderly people attended this march, which was held in total silence. This was the starting point of Peace People Movement in Northern Ireland, 
which later on emerged as a very powerful movement against war and militarism in Ireland and in Western Europe.

Mother Teresa: Mother Teresa was another heroin of peace who was awarded the Nobel Peace Prize in 1979. Mother Teresa was born in a Roman Catholic family in Albania. At the age of 12, she felt the urge to help poor people and at the age of 18, she decided to work in India and started teaching girls in a school in Kolkata. After teaching for 16 years, she decided to work in the slums of Kolkata. She helped people without caring for their religion, caste or nationality. She worked with great devotion and especially served those who were affected with leprosy. Her message to the world was that serving the needy and diseased was a service to peace.

Alva Myrdal: A Swedish citizen, Alva Myrdal, was the co-recipient of the Nobel Peace Prize in 1982-along with Mexican Alfonso Garcia Robles. Myrdal was a staunch champion of women's liberation and equality and she was opposed to the culture of armament. She had also served as her country's ambassador to India. She was the first woman to be appointed as a head of a Swedish delegation to the UN Disarmament Committee. She served in this capacity from 1962 to 1973 . She played a prominent part in developing Sweden as a welfare state and also wrote one of the best books ever on disarmament. Myrdal also worked as Director of UNESCO's Department of Social Sciences in 1951.

Aung San Suu Kyi: Kyi received the Nobel Peace Prize in 1991. Ironically, she was then under military detention in Myanmar (Burma). She still is. She was then represented at the award ceremony by her husband and two sons. The reason for her detention was that she had protested against military dictatorship in her country and was fighting for democracy and peace. She was influenced by Gandhi's non - violence movement and by her father, who was a leader in Myanmar's struggle for liberation and was killed when she was only 2 years old. She has waged a heroic struggle against military dictatorship in her country and refused to bow down before the military or to accept any favour from them. She is internationally respected for her courage, her willingness to suffer for democracy and equal rights for the citizens of Myanmar and for peace and human security everywhere.

Rigoberta Menchu Tum: Tum is a Mayan Indian woman from Guatemala and was the recipient of the Nobel Peace Prize in 1992. She was rewarded the Prize in recognition of her work for social justice and ethno-cultural reconciliation based on respect for the indigenous peoples. She was born in a poor family and therefore was not properly educated. Whatever education she got was from the church. To ease some of the financial problems faced by her family, Tum started to work when she was only eight. She, however, learnt Spanish so that she could be able to promote awareness regarding the plight and suffering of her people to European and other welfare countries. She was also 
exiled to Mexico, as her government did not tolerate her political activities. Government soldiers murdered her mother and brothers because her father had opposed the landowners of their area. Her father was also killed while he was making a peaceful protest against the brutality committed on the people by the government and the landowners. Tum is a source of great inspiration and a symbol of peace and reconciliation across ethnic, cultural and social dividing lines in her own country and in the world at large.

Jody Williams: The life and struggle of Jody Williams, yet another female Nobel Peace laureate, is illustrative of the fact that women can play a great role in fulfilling the dream for global peace and human security. She received the Prize in 1997. She is actively involved in leading and coordinating the International Campaign to Ban Landmines (ICBL) since 1991. She highlighted the human dimensions and focused on the consequences of land mining, especially for women and children. She led a vigorous campaign and convinced states that mining was deadly for all people and all societies. Little wonder that only a week before she received the Nobel Prize, 122 countries had signed the Ottawa Treaty, which outlawed the production of landmines.

Shirin Ebadi: Shirin Ebadi from Iran received the Nobel Peace Prize in 2003. She was awarded this prize in recognition of her campaign for democracy and greater rights for women and children in her country. Her peace activities brought her into conflict with the conservative clerics of her country. Ebadi, who is a mother of two daughters, is the driving force of family laws in Iran. She has also campaigned for changes in the laws for divorce and inheritance. She is her country's first -ever female judge. Ebadi is involved in the campaign for political and social change in a country where discriminations against women are widespread.

Wangari Maathai: Wangari Maathai is the first African woman to ever to win a Nobel Peace Prize. She received this prize in 2004 for promoting ecologically viable, social, economic and cultural development in her country, Kenya and also in Africa. She stood against the oppressive regime in Kenya and also ran for presidential elections in 1997. She was elected to the parliament in 2002 when $98 \%$ of her constituency voted for her. Wangari is a great campaigner of environmental peace and actively advocates in favour of human development and human security.

So far only twelve women have obtained Nobel Peace Prize since its inception in the year 1901. No woman from South Asia has, as yet, received a Nobel Peace Prize. However, this doesn't mean that women from South Asia, including Pakistan, are not interested or not involved in peace action. In fact, the South Asian women are in the forefront of the struggle for political and social change. They have formed several regional and numerous national organizations to campaigns for peace, equal rights and empowerment. They are also involved in the movement to promote peace and co-operation between and among 
the peoples of the region. Due to space constraint, a detailed discussion on South Asian women's struggle for peace and justice is not being included here. It is intended to be covered in a separate paper.

\section{Conclusion}

At the end of this paper on women's peace activism in different regions, the following points may be emphasized :-

- Women's movement for peace, justice and equality is not a 20th century development. In one form or another, women have always voiced their protest against discrimination and injustices against them in different eras.

- Women are, by nature, peace and consensus builders and they are against wars and violence.

- By raising their voice against wars, militarism and nuclearism and by actively campaigning against wars in different countries, women have contributed to the cause of peace.

- The awareness regarding the importance of peace for women and about the peace role of women is on the rise, especially in Europe and North America. But this awareness is also rising-slowly though- in the developing societies as well and especially in the conflict-torn South Asian societies.

- So far only twelve women have obtained Nobel Peace Prize since the inception of the Prize in 1901. No woman from South Asia has, as yet, received a Nobel Peace Prize.

Studies on women's peace role in South Asia and especially in Pakistan are very few and there is clearly a need for study and research in this direction. In this context, a number of questions need to be addressed to. Some of these are: Is there any awareness of the importance of peace in South Asia and especially in Pakistan?; Is South Asian youthinheritor of the responsibilities for peace in the region-aware of the causes and cost of peacelessness in the region ?; Is there any awareness regarding the efforts for building peace between India and Pakistan?; Is there any awareness of women's role in building peace in South Asia?

These and several other related questions and issues are important and need to be attended to and discussed widely. Survival, progress and prosperity of more than onefifth of the population of the world depend, to a great extent, on having a clearer perception of the challenges ahead and a clear understanding of the peace role that can be played by the South Asian women. This role would surely and eventually compliment and supplement the efforts of women of the other parts of the world for peace, human security, prosperity and dignity every where. 


\section{End Notes}

${ }^{1}$ Peace history is a branch of history which has been developed by the scholars with deep interest in human issues and in the struggle of the common people for justice, peace, dignity and security. As an emerging branch of history, it focuses on the ugly side of war and records the efforts and initiatives for peace.

2 Profile of Women Nobel Peace Laureates have been prepared after visiting several websites.

\section{Reference}

Berenice A. Carrol, 'Looking where the Key was Lost: Feminist andNonviolence Theory' in Chaiwat Satha-Anand \& Michael True(eds.), The Frontiers of Nonviolence, Honolulu: Center for Global Nonviolence,1988, PP.19-33.

Betty Reardon, Women and Peace: Feminist Visions of Global Security, New York: State University of New York, 1993,P108.

Utne, Brigit Brock (1985). Education for Peace: A Feminist Perspective, New York: Pergamon Press, PP. 37-45.

Ibid, P.37.

Ibid,P.45.

Ibid, PP.46-47.

Ibid,P.48.

Ibid, P.48-50.

Ibid, P.50.

Ibid.

United Nations, The United Nations and the Advancement of Women, 1945-1995, United nations, New York, PP. 33-36.

http://www.un.org/conferences/women/pubfo/status/scrn5.htm (accessed on 14 October 2007 ).

http://www.un.org/conferences/women/pubfo/status/scrn5.htm(accessed on 14 October $2007)$. 
Nafisa Bano, is lecturer at the Centre of Excellence for Women's Studies University of Karachi. She is enrolled in M.S programme. Her area of interest is Women Development and Peace. 